\title{
Working the Socio-Natural Relations of the Urban Waterscape in South Africa
}

\author{
ALEX LOFTUS
}

\begin{abstract}
In this article I seek to bring together recent work on 'the production of nature' with feminist standpoint theories. I do this in order to explore some of the potentials for democratic change in the South African city of Durban. In spite of the shared methodological assumptions of the two bodies of work, there has been little effort to develop a dialogue. In initiating this, I begin by outlining some of the theoretical foundations underlying the two theories. Then I go on to suggest some of the ways in which a relational approach to urban environments sheds light upon the politics of water service provision in Durban. From this, I suggest that a feminist standpoint approach might open up different possibilities for democratic change. However, I argue that this should begin not from a romantic view of some untainted or non-reified consciousness of the socio-natural but rather from the situated knowledges that emerge from the struggle to survive in a world defined by both capitalist and non-capitalist social relationships.
\end{abstract}

\section{Introduction}

This article begins from a position of political despondency and pessimism before charting a journey towards an urban ecological politics of hope. This sense of hope emerges from the quotidian act of ensuring a household has sufficient access to water. In Durban, this activity is frequently defined by a process of everyday struggle that enables insights into the politics of the city not necessarily available to those in dominant positions. Such insights could foreground a radical urban environmental politics. Thus, in the process of negotiating with water service providers, in battling municipal disconnection bailiffs and in queuing at community standpipes, those working the socionatural relations of Durban's waterscape actively develop distinctive, situated knowledges of the environmental politics of the city. These knowledges could form the basis for alternative freedom projects. In developing this urban ecological politics of hope, the article seeks to initiate a conversation between work on the production of nature (Smith, 1984; Harvey, 1996; Heynen et al., 2006) and feminist standpoint theories (Hartsock, 1983a; 1983b; Harding, 1986; Haraway, 1991). My approach draws inspiration from both, in order to reinterpret the environmental politics of the city. Whilst the two bodies of work share common methodological foundations, synergies have not, so far, been explored. ${ }^{1}$

Many thanks to Mike Ekers, Fiona Lumsden, Erik Swyngedouw and two anonymous referees for commenting on various versions of this article. And thanks to those residents of Inanda, especially Thulani Ncwane, who played such a crucial role in taking these ideas forward.

1 Whilst there is a vast, rich and diverse literature on both ecofeminisms and gender-environment relationships, the Lukácsian starting point for Hartsock's standpoint feminism (as explored in this article) takes us in quite different directions. I discuss this more later in the article. 
The example of Durban is of particular interest. Water service provision in the city is currently undergoing rapid changes. New technological advances have been directed at providing access to water for hundreds of thousands of new consumers. At the same time, associated developments have been directed at limiting the access of those unable to pay for rising bills. Periodically, upsurges in militancy across the city show the anger felt by those with large payment arrears, those who have been disconnected and those whose water has been restricted. The majority of participants (though not always the leaders) in such protests are women. My aim, however, is not to romanticize the struggles of 'militant third-world woman' (for such a criticism see Mohanty, 1988). Rather it is to make a claim that the struggle to negotiate this changing politics of water often necessitates particular forms of knowledge that are not available to others. In turn, this opens up conditions of possibility for revolutionary thinking about the environmental politics of the city.

This claim stems from the ontological and epistemological priority given to sensuous human activity in theories of 'the production of nature' and of feminist standpoint theories (Hartsock, 1983a; 1983b; Smith, 1984; Swyngedouw, 2006). Environments are produced through work and play: the ways in which we think about those environments are grounded in the knowledges developed through our work and play. Whereas writings on the production of nature have focused on developing such a relational ontology, writings in feminist standpoint theory have focused on the epistemological. The former has shown the shifting historical relationships in the production of created ecosystems or lived environments. The latter has focused on the struggle for different knowledges. Importantly, and in addition, feminist standpoint theory has developed a more diverse understanding of the social relationships embodied in particular socio-natures (Haraway, 1993; Hartsock, 1998). By stressing historical materialists' neglect of the gendered division of labour, feminist standpoint theories have helped to emphasize the crosscutting — and articulated - power relationships (be these around gender, race, sexuality, age or whatever) against which people struggle and from which different knowledges are made possible (Harding, 2004). Bringing the two bodies of work together makes possible both a richer understanding of urban environments and new entry points for political intervention.

Although my aim in the article is to initiate a conversation between two bodies of thought, the suggestion for this comes from empirical research conducted in Durban. Community workshops and semi-structured interviews were held in three areas of the city - a rural community, an informal settlement and a formal township. The insights from these workshops and the interviews conducted are not presented as decisive conclusions. Rather, they provide suggestions about political possibilities. In this regard, I do not consider a standpoint (be it feminist or otherwise) to be a fixed and definable 'perspective' on the world, testable through empirical observation, but rather a form of knowledge produced through a process of struggle that has emancipatory potential (Haraway, 1996; Hartsock, 1998; Jameson, 2004). The interviews thereby provide pointers to a possible alternative politics, even if that politics is only nascent.

I begin the article by outlining the methodological approach to understanding urban environments that emerges in recent work on the production of nature. I then go on to look at feminist standpoint theory, focusing in particular on the work of Nancy Hartsock (1983a; 1983b). Here I emphasize some of the possible synergies with the production of nature thesis. Then I seek to show some of the insights into Durban's water politics opened up by a relational approach to urban environments, before going on to suggest how this might be radicalized with greater attention being paid to situated knowledges. Throughout, I seek to avoid developing a romantic sense of some non-capitalist sphere of reproduction. I conclude with a brief vignette from a protest around water politics that took place in the informal settlement of Amaoti in 2003, a protest suggestive of several political possibilities. 


\section{Producing urban political ecologies}

The relationship between people and the environments in which they live has been a long-standing question of social and geographical theory. Responses to questions around this relationship have tended to range between the extremes of environmental determinism and social constructivism. The approach I adopt in this article avoids these positions by focusing instead upon the internal, mutually constitutive relationships within and between humans and non-human entities (Smith, 1984; Harvey, 1996; Swyngedouw, 1999; Castree, 2002; Whatmore, 2002). Whilst Deep Ecologists propose one particular route into understanding the 'spiritual' workings of this interconnection (Naess, 1989), I develop an explicitly historical materialist approach to understanding the manner in which humans and non-humans are brought together in a differentiated unity (Harvey, 1996). Crucial to such an approach is the sensuous human activity that fulfils particular historically defined social needs: in short, work is of fundamental importance (Marx, 1974). Through working, people are brought into contact with nonhuman entities and establish particular relationships that give meaning to and shape the created ecosystems of which they are a part. Neil Smith's seminal text, Uneven Development (1984), is crucial in the development of such an approach. In this, he develops the quixotic, yet fecund, idea that nature is produced.

Part of Smith's aim is to demolish the romantic, bourgeois notion that nature is that which is untouched by human activity, antithetical to the development of cities, and politically neutral. In contrast, Smith suggests - with virtually nowhere in the world being 'free' from human activity, codification, quantification or navigation - it makes little sense to cling to the hope of an illusory, pristine nature. Instead, nature is politicized. The environment might then be understood (as with the environmental justice movement) to be the toxic dump located next to the working-class Latino family (Bullard, 1993). It might be understood to be the exhaust fumes breathed by the cyclist struggling home, or the stuffy air inside the car being driven in front. Of course it is also far more than this, but what such an approach urges us to focus on are the particular historical relationships through which people and natures have been brought into tense, differentiated unities. It urges us to look at the inequalities produced through these relationships and at struggles for justice within politicized natures. For Smith, as with Marx, defining moments lie in the transition from feudalism to capitalism and in the transition from capitalism operating on a national scale to its operation on a global scale. A direct relationship is thereby transformed into one mediated by exchange relations. Here, Smith transforms the conventional understanding of first and second nature by writing of a 'produced first nature' and a second nature produced through capitalist social relations. With capitalism operating on a global scale, Smith writes, human labour produces first nature, human relations produce second. The main purpose of this account is actually to develop an understanding of the production of space, and from here to understand some of the dynamics of uneven development. For others, building on Smith's work, the importance lies in the suggestion that alternative forms of socionatural organization might be possible. Alternative political ecologies might be envisioned through an understanding of the socio-natural relations to which Smith directs our attention (1984: 32-65).

In part inspired by Smith's work, several of these basic historical materialist premises have been taken up in new and lively ways in recent writings on urban political ecologies (Swyngedouw and Heynen, 2003; Desfor and Keil, 2004; Heynen et al., 2006). This approach differs somewhat from the traditions of political ecology identified in recent works by Robbins (2004), Zimmerer and Bassett (2003) or Peet and Watts (2004). Robbins (2004) charts the development of radical approaches to political ecology from a North American cultural ecology tradition. He considers the critical and the normative (the hatchet and the seed) to be fundamental to any political ecology approach. Whilst this is no doubt crucial to much of the work in the Heynen, Kaika and Swyngedouw collection, I would suggest that the threads that might tie much of this work together 
is, in contrast, a fascination with the internal relationships through which nature is urbanized and the city is produced as a particular nature. ${ }^{2}$ This opens up possibilities for reading the politicized environments of cities (Swyngedouw et al., 2002). In Swyngedouw's work we see the production of a scalar politics through struggles over the socio-natural relationships of the city. He turns this to understanding the political transformations of both Ecuador and Spain (Swyngedouw 1997; 1999; 2004), in the latter demonstrating how hydropolitics and Fascism came to be intertwined in complex and revealing ways (Swyngedouw, forthcoming). In Kaika's work (2005), the cultural and political are brought together to show how visions of modernity are both embodied in and realized through the built infrastructure of the waterscape. In Heynen's (2006) recent writings, a framework is provided for teasing out some of the relations that produce urban hunger.

Such work has helped to enrich our understanding of the different relationships that make up the unequal environment of cities. It provides both a lens through which to view the socio-natural relations of the city, as well as a means for thinking through alternative geographical projects. For some, this has been facilitated by an engagement with Haraway's (1991) writings on the cyborg. Thus, Gandy's (2005a) review of the literature on cyborg urbanization makes clear the possibilities within the trope. His explorations of some of the complex and unequal relationships through which urban natures are produced as socio-natural hybrids in New York (2002), Lagos (2005b) and Mumbai (forthcoming) are highly instructive. Given Haraway's explicit concern to develop a feminist politics, and given the shared methodological assumptions in Haraway's work, it remains curious that the work of feminist theorists has not yet been put to use in the development of a feminist urban political ecology. Page's (2005) important engagement with Lacanian psychoanalysis offers several hopeful possibilities. His references to protests comprising militant women also suggest areas of crossfertilization, although his understanding of commodity fetishism and reification as an illusory process that might be 'unmasked' differs in important ways from the theoretical framework, grounded in human activity, developed here. Through exploring feminist standpoint approaches, a major source of inspiration and debate in Haraway's work, I seek to address some of the absences in urban political ecological work.

To summarize, recent work on the production of natures offers a powerful analytical device for interpreting the politics of urban environments. Such devices are taken up in this article as a way of understanding some of the paradoxes of Durban's water service provision. Here, I argue for the importance of paying particular attention to: the ontological and epistemological importance of human activity; the internalization of socio-natural relationships in the built infrastructure of cities; processes of transformation; and issues of socio-ecological justice. However, such work has not yet engaged with feminist concerns. This is not necessarily a failing of the approach, but rather the uses to which it has been put. Entry points for democratic socio-ecological change remain limited by this. In the next section, I suggest that an engagement with feminist standpoint approaches might open up both the possibility of a rich conversation with feminist theories, as well as a route towards reinterpreting the possibilities for democratic social change.

\section{Feminist standpoints and situated knowledges}

The methodological starting point for some standpoint theorists is almost identical to that in the production of nature thesis. ${ }^{3}$ Sensuous activity is viewed as crucial to: (1) the make-up of our world; (2) the meanings that are invested in that world; and (3) the

2 There are clear differences with the structurally-inspired work of seminal texts such as Blaikie's (1985) The Political Economy of Soil Erosion. Blaikie's focus is on external power relations that produce certain environmental effects.

3 It is tempting to deduce too much from the 1980s Johns Hopkins' reading group on Marx organized by David Harvey, Donna Haraway, Neil Smith and Nancy Hartsock. 
particular understandings made possible. Environments are produced through the act of working with and transforming material things. For Hartsock (as for Smith), this builds on a marxist insistence on the epistemological and ontological priority of human activity. Thus:

The epistemological (and even ontological) significance of human activity is made clear in Marx's argument not only that persons are active but that reality itself consists of 'sensuous human activity, practice' (Hartsock 1983b: 118).

For Hartsock, feminist theorists' frustration with historical materialist approaches lies in their narrow interpretation of human activity (see Hartmann, 1981). Work is taken to mean wage labour and the division of labour is seen to refer to that between worker and capitalist, rather than between men and women. In contrast, by focusing attention on the gendered division of labour, feminist standpoint theorists bring a focus on capitalist patriarchy to the fore. Beyond such a critique, Hartsock emphasizes the marxist claim that the relationships established through this work process provide different vantage points upon the totality of relations comprising society (Marx, 1976: 279-80; Ollman, 1973; Harvey, 1982). Thus, in Capital, the struggle for a proletarian standpoint is seen as crucial to unlocking the secrets of the workings of capitalism. It is only through descending to the hidden abode of production that Marx is able to leave the noisy sphere of exchange and contemplate the relevance of surplus value production. Capital is thus an attempt to develop a critique of political economy from the standpoint of a worker. Lukács (1971) was to take this insight and develop an impressive account of how both encroaching bureaucratic rationality and commodity fetishism serve to produce a perverted reality that only workers are in a position to see the foundations of. Through a unique position in the production process, Lukács argues, the proletariat is able to see the socio-natural processes producing the reified reality of capitalism. More recently, John Holloway's explosive autonomous marxist work, Change the World Without Taking Power (2002), has developed this into an account of the everyday resistances against 'fetishization as process'. In a previous article, I suggested that Durban's waterscape is produced through such reifiying processes, and the challenge for a progressive politics was to be able to fight against reification and intervene in the production of a democratic waterscape (Loftus, 2006b). In this article, I argue that standpoint approaches offer one way of challenging such reifying processes.

For Hartsock, such potential lies in exploring the work of women who, in societies shaped by both capitalist and patriarchal relations are brought much closer to the material interchange with nature that Lukács and Marx saw as being so important to challenging the fetishism of the modern world.

Given what has been said about the life activity of the proletarian, one can see that, because the gendered division of labour means that much of the work involved in reproducing labour power is done by women, and because much of the male worker's contact with nature outside the factory is mediated by women, the vision of reality which grows from the female experience is deeper and more thoroughgoing than that available to the worker (Hartsock, 1983b: 118).

There are several possible criticisms of such an approach. Some of Hartsock's early writing might be considered to be essentialist (see New, 1997, amongst others). The 'female experience' as Hartsock describes it, is surely likely to differ depending on one's relation to other forms of domination, whether along the lines of race, class or sexuality. To suggest that one group's vision is 'privileged' (as Hartsock does somewhat uncritically in her early writings, although later [1998] she pluralizes the notion of standpoint considerably) is to perform the very 'god-trick' that standpoint theorists had originally sought to subvert through their stress on the importance of location (Haraway 1991). As Haraway (ibid.) goes on to remind us, all knowledges are necessarily partial. Because of this, some consider Hartsock to have merely inverted patriarchal power 
relations through a simplistic and binarized model (New, 1997; see Plumwood, 1993: 5 , on the perils of inversion).

As Hartsock (1998) notes, many of the critiques of her work fail to recognize the crucial way in which it represents a transformation of the Lukácsian (and marxist) concept of the proletarian standpoint. The same criticism can be levelled at New (1997) who uncritically positions Hartsock's work alongside ecofeminist writings. Whilst there is a crucial strand of ecofeminist thought that recognizes the importance of work in shaping gender-environment relations (see Agarwal, 1992; Merchant, 1992; Nesmith and Radcliffe, 1993; Plumwood, 1993; Sachs, 1994), the position adopted is often radically at odds with that taken in Hartsock's standpoint theory. Because of her emphasis on the conditions of possibility for alternative epistemologies (Hartsock, 1998; Jameson, 2004), Hartsock's position is frequently far less essentializing than the variants of ecofeminism (see Nightingale, 2006 for the distinction between essentialist and materialist ecofeminisms). Because of her foundations in the 'unfinished project of History and Class Consciousness' (Jameson, 2004), she also leaves open far greater possibility for exploring relationships between work, feminism and the commodity economy. ${ }^{4}$

Standpoint theories have continued to develop through productive exchanges. Thus, Haraway's response to essentializing tendencies was to develop a highly influential discussion of 'situated knowledges' (1991). Having sharpened much of her work in debate with standpoint theorists, Haraway is keen to stress what remains of value in the tainted metaphor of the 'standpoint' or 'perspective':

A standpoint is not an empiricist appeal to or by 'the oppressed' but a cognitive, psychological, and political tool for more adequate knowledge judged by the nonessentialist, historically contingent, situated standards of strong objectivity. Such a standpoint is the always fraught but necessary fruit of the practice of oppositional and differential consciousness. A feminist standpoint is a practical technology rooted in yearning, not an abstract philosophical foundation (Haraway 1996: 198-9; see also Haraway, 2004).

Again, in a later response, Hartsock takes on board many of these criticisms, arguing for the need to pluralize standpoints around axes of difference. The approach adopted in this article draws inspiration from both Hartsock's early work and Haraway's developed sense of situated knowledges. Both theorists' work is testimony to the immensely productive insights that can be gleaned from standpoint approaches in broadening our understanding of produced natures. First, feminist standpoint theory stresses the epistemological insights that might be gained from a critical approach to urban political ecology. Produced environments are comprised of a range of socionatural relationships and lines of domination. This permits a range of different perspectives on the lived environment, depending on one's own relationship - as a producer or a consumer and so on (see also Ollman, 1973; Harvey, 1982). Secondly, feminist standpoint theorists stress the importance of struggle in gaining a sense of these relationships. Groups of people who are subordinated in power relationships are involved in a process of struggle from which the psychological and political tool of standpoint theory might be developed (Eagleton, 1994). Whilst everyday struggles might not be self-consciously political, they have the potential for becoming so. Katz's (2004) interest in developing 'counter-topographies' of power could be seen as a possible model here. Her work avoids essentializing 'the female experience' by emphasizing the active process of constructing alternative forms of knowledge. Thirdly, feminist standpoint theory might provide the possibility of exploring alternative futures that go beyond the reified world of the capitalist economy (Jameson, 2004). Overall, feminist standpoint theory provides the opportunity for urban political ecology to engage with a range of socio-natural relationships in addition to the capital-labour relation. At the same time,

4 It is because of this, and because of the worn and circuitous debates around ecofeminisms, that I do not discuss this literature in greater depth. 
it provides the chance for a radical new take on democratic possibilities. In the following section I begin by developing some of the insights that might emerge from a flexible and open urban political ecological analysis of Durban's waterscape, before going on to look at the insights that might be gleaned from bringing this into conversation with a feminist standpoint approach.

\section{Producing Durban's waterscape: everyday struggles}

On the surface, Durban has made major advances over the last decade and a half towards socio-ecological equity in the distribution of water in the city: conflict between consumers and the municipality has, however, continually flared up. The approach to produced natures outlined earlier assists in teasing out some of the generative processes underlying this situation. On the positive side, 100,000 new households have been connected to the water network since the end of apartheid. Assuming an average household size of four (and this could well be an underestimate considering the larger household sizes of many poor families), 400,000 people have benefited from potable water (interview Macleod, 26 March 2003). The speed with which eThekwini Water Services has expanded the network is related to the entity's willingness to experiment with a range of medium-technology alternatives to full-pressure connections (Palmer Development Group, 2000). Thus, a groundtank system has been developed which permits households in informal areas to tap into a full-pressure network with low-grade piping. A central manifold reduces water pressure before distributing water to ten or more households through the equivalent of hose-piping. This water then fills a sealed 200 litre tank. Through developing such a system, the municipality has been able to reduce water-borne diseases, cut-down on journey times to and from a standpipe and also regulate access to a fixed amount of water (Macleod, 1997). Because of this, the municipality went on to develop an even more ambitious universal free basic water policy. By developing a tariff system that charges residents a fixed amount per kilolitre that is, in turn, dependent on the overall volume of water consumed (see Table 1), it has become possible to cross-subsidize the water use of those consuming the least, with higher charges being made to those consuming the most. According to local lore, Durban was the pioneer in South Africa with such a policy before it was launched as a national initiative (Kasrils, 2000).

Those receiving the clearest benefits of the new technology are those living in rural areas of the municipality. The network has only recently been extended to such places and - with water being delivered through the ground tank system - residents have not encountered the same difficulties with payments as those in townships and informal settlements. As part of this research, I conducted semi-structured interviews with 20

Table 1 Charges in Rand/kl of water consumed as of July 2006

\begin{tabular}{|c|c|c|c|c|}
\hline $\begin{array}{l}\text { Monthly } \\
\text { Consumption }\end{array}$ & $\begin{array}{l}\text { Ground Tank } \\
\text { (low pressure) }\end{array}$ & $\begin{array}{c}\text { Roof Tank } \\
\text { (semi-pressure system) }\end{array}$ & $\begin{array}{c}\text { Domestic } \\
\text { (full pressure) }\end{array}$ & $\begin{array}{c}\text { Industrial, } \\
\text { commercial, } \\
\text { and other users }\end{array}$ \\
\hline $0 \mathrm{kl}$ to $6 \mathrm{kl}$ & nil & nil & nil & 6.27 \\
\hline from $6 \mathrm{kl}$ to $30 \mathrm{kl}$ & $\mathrm{n} / \mathrm{a}$ & 4.16 & 6.27 & 6.27 \\
\hline more than $30 \mathrm{kl}$ & $\mathrm{n} / \mathrm{a}$ & 12.53 & 12.53 & 6.27 \\
\hline fixed charge & nil & nil & $\begin{array}{r}0 \\
-48.90\end{array}$ & $\begin{array}{r}55.75 \\
-5,575.08\end{array}$ \\
\hline
\end{tabular}

Source: http://www.durban.gov.za/eThekwini/Services/water_and_sanitation/bylaws_and_tariffs/Water_Tariffs_ English 
residents in the Mzinyathi area of the municipality, a loosely defined area on the banks of the Inanda dam. Until very recently, most households had relied on collecting water from the dam, with all of those interviewed living within $2 \mathrm{~km}$ of the water's edge. The stark paradoxes of apartheid are made clear through the construction of the reservoir as an attempt to sate the rising thirst of an urban population in the 1980s. It took almost 20 years for those displaced by its construction to actually receive any of the clean water. For each of the 20 households, prior to the arrival of an on-site supply, women and children had worked for between half an hour and four hours a day to carry loads of water from this reservoir to their households (household interviews, Mzinyathi). Some commented that, in the latter years of apartheid, bodies would surface in the stagnant waters from which they collected their supply. A crippled woman spoke of her newfound independence as she no longer felt reliant on the work of others to bring her water. She could now make a cup of tea for herself and not have to fear a thirsty night ahead. Having paid for the ground tanks, these residents were not faced with daily charges for water. Although a technical glitch meant that the municipality was currently unable to regulate supplies to the basic minimum, eventually this would be the case and residents would receive no more than 200 litres of water per day.

In other areas of the city, particularly in townships and informal settlements, this picture is much less positive. The trade-off with the municipality for receiving a free basic water allowance has been a stepped tariff that appears to leave many township households particularly vulnerable to increased charges. In addition, by extending the free basic allowance to all residents, the municipality has found itself increasingly under pressure to reduce the consumption of other residents. The aim of the stepped tariff structure was to target those using the most - the reasonable assumption at the time was that the wealthiest residents, with the most appliances, would use the most water: they could, fairly, be targeted by an increase in charges. However, whilst the tariff mechanism did indeed reduce this consumption a little, the largest reductions in consumption came about amongst those most needy (Bailey, 2005). Part of this adjustment came about through poor residents modifying their own behaviour. However, the municipality also played an active role in reducing many households' consumption to a level around the free basic minimum through installing a range of restrictive devices. Often, the devices serve to reduce consumption to a level below the free basic allowance. In addition, the municipality implemented a much harsher approach to those who amassed arrears. At the time of research, around 1,000 household disconnections or restrictions were taking place daily. Whilst pressure from civil society groups, including a legal challenge to the policy of disconnections, forced eThekwini Water Services to change its policy of disconnecting residents to one of restricting residents' supplies, the outcome was often qualitatively the same. Indeed, numerous cases of disconnections have taken place after the apparent change in municipal policy.

To begin to tease out the processes generating the paradoxes of Durban's free water experiments, it is helpful to consider the historically changing relationships making up the water politics of the city. Building on Smith's (1984) writings, Durban's waterscape is seen to be produced through active work (walking to and from standpipes, making trips to the municipality to negotiate bills) and through social relationships (between municipality and consumer, men and women, and municipality and bulk-water provider). In recent times, there have been several key moments in which these relationships have transformed. The first is in the early 1970s when universal water metering was introduced. This allowed for a far greater bureaucratic manipulation of water usage. The rise of formal rationality in the state bureaucracy (Weber, 1968) is shown through the increasing emphasis throughout the 1960s on developing what was considered to be a rational distribution of water, based on the (irrational) racist priorities of apartheid (for an example see Kinmont, 1959). The relationship between consumers of water and those providing that water came to be increasingly mediated through bureaucratic mechanisms. 
Another key moment emerged in 1983. From this time onwards, the municipality has been compelled to purchase all water supplies from the Umgeni Water Board. With the quasi-commercial functioning of this water board, Durban's water has been transformed into both a profitable resource and a political tool. Thus, in the mid-1980s, water served both a legitimizing function for the apartheid government's ambitions, as well as becoming an active moment in the accumulation of capital. Although the municipality had been responsible for constructing much of the bulk-water infrastructure supplying the city, the national government insisted on the sale of this infrastructure to a water board. This would serve as bulk-supplier to Pietermaritzburg, Durban and the KwaZulu Bantustan. The justification for this development was that a third party would be necessary to mediate the use of water between different municipalities. The reality was that this third party was necessary to provide greater legitimacy to the apartheid government's policy of 'separate development' for KwaZulu. Apartheid would be undermined if a municipality was seen to be selling water to what the government hoped would become a separate state. Tensions between the municipality and the water board were high from the start, with the municipality willing to sell its infrastructure only for a vastly inflated price. The water board then responded by increasing bulk-water charges to the city year-on-year.

With water boards receiving new commercial freedoms to compete with private service providers in the post-apartheid era, the exchange relation was heightened within the waterscape. Umgeni Water then went on to make several poor commercial decisions. In spite of the fact that its bulk-water provision was said to be ring-fenced from its commercial functions, the entity's response was to try and regain its profit levels by increasing the cost of bulk-water sales to the city. Having been given great freedoms to borrow in the 1990s, Umgeni Water found itself awash with capital but unable to find profitable outlets for this. When it failed to find profitable outlets in which to invest this abroad, or through prising the emerging water services market open further at home, bulk-water sales were the most obvious area in which to seek profitable investments. Durban's waterscape thereby began to be transformed into a particular accumulation strategy. The water that now circulates through Durban is more closely tied than ever to the whims of the South African Bond market (Loftus, 2004; 2006a).

For residents of Durban's townships and informal settlements, the transformation of the waterscape in this way has several direct effects. First, for those receiving water bills these are estimated to be $30 \%$ higher than if Umgeni Water did not exist (interview Macleod, 26 March 2003). ${ }^{5}$ Secondly, residents are much more likely to experience some form of disconnection or restriction to their supplies because of the pressure on the municipality to meet the costs of bulk-water purchases. Related to this is a third point: residents are experiencing a strange transformation in the power of water infrastructure, as it begins to regulate the rhythms of daily life. Repeatedly, residents cited the power of the water meter as an inhuman agent working within their homes. The associated technologies that serve to restrict and limit supplies work in harmony with the water meter to bureaucratically manipulate consumption to the bare minimum considered necessary for survival. Grassroots anger is frequently directed at challenging this inhuman power.

What we witness in this 'dictatorship of the water meter' is an inversion of people and 'things'. The shifting social relationships between bondholders and water users come to be embodied within both water and water infrastructure. The waterscape, in short, should be understood as a produced socio-natural entity. It is produced directly through the urbanization of nature involved in the damming of the Umgeni River, the diverting of its flow and the construction of the vast infrastructure to distribute potable water to the many residents of the city. In recent years the waterscape must also be seen to be produced through the reifying social relationships of late capitalism (Lukács, 1971; Smith, 1984). Through understanding how these relations become embodied in the 
everydayness of 'things', we begin to see how local waters and global capital are part of a differentiated, dialectical unity. We see how everyday acts of collecting water from standpipes, kiosks and ground tanks are both productive of the social relations that comprise the waterscape, as well as reproductive of certain forms of accumulation. Perhaps also, we begin to see inroads into a politics that might begin to transform the relations that are embodied within the waterscape. Whilst critical assessment is made possible through looking at these internal relations, an emancipatory politics might come through exploring the situated knowledges of those engaged in working the socio-natural relations of the urban waterscape. Central to such work is the gendered division of labour.

\section{Reproducing gendered divisions of labour}

In all three areas of the city in which research was conducted, women performed the vast majority of work in provisioning the household with potable water. This gendered division of labour takes a different form depending on the specific area in which it operates. Thus, in Bhambayi, a locale within the larger informal settlement of Inanda, women were responsible for a daily trek to and from a standpipe. In KwaMashu C, in contrast, bills were registered in the name of women and responsibilities were instead centred on juggling the finances of the household. In Mzinyathi, with the arrival of ground tanks, women had gained a modicum of freedom from the task of trekking to and from the Inanda dam in order to collect supplies. Repeatedly, both community workshops and follow-up household interviews confirmed the crucial role of women in carrying out the work necessary for the continued reproduction of the waterscape. The following conversation, in which the continuing gendered division of labour is emphasized is taken from a community workshop in Bhambayi (5 March 2003):

Young Woman: Even for people who come to meetings and are supposedly progressive, women still collect water.

Young Man: But, what about all the single men who live in Bhambayi, they have to collect their own water.

Second Young Man: Women should still fetch water.

Young Woman: Even when men have to collect water out of need, they would rather find some way out of the situation because of the embarrassment. If men are plastering a house, women go again and again for water for them.

Old Man: If you go out now, it's highly possible men will be collecting water in a wheelbarrow. Young Woman: Yes, that's true but the general norm is for women to collect water. It's because of economic constraints that men are fetching water in wheelbarrows. Men are using it for a business. You never see them with just one bucket, always with a wheelbarrow. When you see men, they will be delivering it to the elderly or the sick for money.

Second Young Woman: $85 \%$ are still women but 15\% would now be men.

Young Man: No, more men than that. Even if it is not for business men will collect water, even though the expectation is for women to do this. You'll be faced with questions: 'Is your wife sick'. Men are collecting water but the societal norm is otherwise and as a man collecting water you have to face this.

Earlier attempts to theorize this gendered division of labour often resulted in functionalist accounts of the ability of capital to exploit the household through its dependence on the unpaid labour of women. Thus, for Wolpe (1972), apartheid was seen to be a response to the declining conditions in the Reserves, in which it was becoming harder for women's unpaid labour to support the household. Growing militancy amongst a migrant labour force resulted in a hard-line response from the government in the form of apartheid. Wolpe's account has many similarities to Meillassoux's (1981) understanding of ongoing primitive accumulation, manifest in the exploitation of a domestic economy. Both accounts fail to consider the agency of women and produce 
problematic structural-functionalist accounts (for a further exploration of the possibilities and limitations of these, see Loftus, 2005).

My concern in this article, however, is not to explain the persistence of the gendered division of labour but rather to consider some of the potential that might emerge from the situated knowledges of the waterscape developed through the everyday activity of provisioning the household with water. Some of this potential is suggested in the exchange at the Bhambayi community workshop. Here, men are happy to be seen carrying water if it is clear that their relation with the waterscape is for economic gain. Their knowledge of the waterscape is one developed through the exchange abstraction. This leads to a reified consciousness in Lukács's terms (1971). For women, the situation might be seen to be different. ${ }^{6}$ In the next section, I consider this in more depth through developing and then rejecting the idea that women's work permits what might be understood as a non-reified consciousness of the waterscape.

\section{The romance of a non-reified consciousness}

In Frederic Jameson's (2004) brilliant reconsideration of the contribution of feminist standpoint theory to the 'unfinished project of History and Class Consciousness', a nonreified consciousness is one of the key 'conditions of possibility'. The reified world described earlier, in which water meters have acquired a shadowy dictatorship, might be dissolved through the non-reified consciousness of women. With women's work being defined less by the exchange abstraction and more by the sensuous labour needed to bring up one's family, a different worldview might be achievable. In turn, this could provide a radically different understanding of the processes shaping the waterscape. It could also foreground a radically different politics. Such a position forms the basis for many of the claims made by social ecofeminists (Agarwal, 1992; Nesmith and Radcliffe, 1993). Women's relationship to the environment is therefore viewed as more direct: it is not mediated through the exchange abstraction. Thinking this through in the terms suggested by Smith (1984), first nature is produced through women's labour, and second nature through the social relations involved in men's work in the commoditized economy. Without romanticizing work in non-capitalist societies, our political struggles might, therefore, be directed at regaining the direct, sensuous work involved in producing first nature and rejecting the alienating production of second nature.

New (1997) is quick to dismiss such a romantic view of women's unpaid work:

With their hands covered with shit and their breasts leaking in response to babies' cries, women are supposedly more down to earth, more respecting of all forms of life; too sensible not to see that biodiversity and a future for all our descendants must be valued above capital accumulation (New, 1997: 85).

For the purposes of this research, such a view also overlooks the fact that in all three areas of Durban in which research was conducted, women have repeatedly had to struggle to procure water in a world defined by both capitalist accumulation and by noncapitalist relationships. In Mzinyathi, water is currently being received 'for free', but the situation is in flux, dependent on new technologies being implemented by the municipality. Indeed, the ground tank itself had to be paid for by individual households. In Bhambayi, although water kiosks have given way to free water standpipes, the decision to implement these technologies was dependent on a wider set of factors and, above all, cost-benefit decisions. In KwaMashu C, women remain responsible for paying the water bill, negotiating water rates and ensuring reconnection to the water supply.

6 As will be seen, this is not to argue that capitalist exploitation dominates other forms such as patriarchy. However, I do think that alienation and reification (as understood here) are specific to capitalist forms of work because of the manner in which products are radically separated from producers (see also Lukács (1971: ix-xxxviii) on the distinction between objectification and alienation). 
Indeed, as well as being impossible, it makes little sense to try and separate a pure non-capitalist world from a tainted capitalist world of commodity production and exchange. As Bakker and Gill (2003) argue, social reproduction is increasingly defined through commodity relations, as neoliberalization comes to reshape struggles for existence. Or as Smith (1984) suggested, almost nowhere in the world does nature exist outside of human (in this case, capitalist) relations (see also Marx and Engels, 1970). And as Hartsock (1983a; 1983b) argues, to theorize in terms of separate spheres of production and reproduction is to reproduce the dual systems logic that a feminist historical materialism might undermine (see also Young, 1981).

This point is confirmed in the township areas of the city where the effects of water metering and a restructured tariff mechanism have been experienced most profoundly. It is here that any perceived boundary between a commoditized economy and a romantic world of the household is most clearly shattered. Daily, performing the work required to ensure the healthy survival of one's household involves negotiating the contradictions embodied within the commodity form. This is shown in the following quotation, as the need for the interviewee to conserve water (exchange value) appears to rub up against her assumed role as carer (water as use value):

I am almost always responsible for paying and my only income is from my pension. They said I had a leak in my toilet so I went to buy the new toilet but the bills are still expensive. Every time when the young ones go to the toilet, I don't let them flush it. They can't reach it. So I flush it only afterwards. They can't put me in jail ... can't put me in jail. They told me to pay 70 something. They will think we've been playing with the water. My pension is R600 and the bill is R400. How can I pay this? (interview Zuma, 18 March 2003).?

The interviewee's comments show the awkward role she is forced to perform, as both 'economic woman' measuring every last drop of water, and the caring grandmother who flushes the toilet for 'the young ones' or who ensures she pays all she is able to in order to keep the family safe and well. Rather than occupying a romantic, untainted world of use-values, she is required to negotiate the dialectics of use and exchange value on a daily basis. In another interview, the task of washing clothes becomes the participant's reference point for the contradictions embodied within the commodity form. Again, reproductive and unalienated labour is intertwined with the alienation of the exchange abstraction in contradictory ways: it begins to seem impossible to carry out one's role as carer, without respecting the logic of the commodity.

It could be washing that uses the most amount of water. I'm not sure why the bill is pushing up. If washing, I try and limit the number of times I rinse clothes out. Water used to leak a little bit at the toilet but we've fixed that leak up. We normally have a shower once or twice a day. The disconnection lasted for a matter of a week. During this time water was coming through very slowly though. The father of the house went to Metro once in order to negotiate slow payment through instalments, paying this off. No advice was given to us though, just advice on payment (interview Gwala, 18 March 2003). ${ }^{8}$

As with the previous interview, a caring role is in a tense relationship with the enforced sense of the commodified nature of water, the activity of washing, presumably carried out at least every other day, and the importance of only rinsing clothes out once or twice falling on the woman of the house. In Weber's (1968) terms, formal rationality is seen to conflict with substantive rationality on a daily basis, something he saw to be at the heart of societal protests. Other comments from interviews, conducted on the same day in Section $\mathrm{C}$ of KwaMashu echo such a position.

7 All references to interviews conducted on the 18 March are household interviews conducted in the KwaMashu area.

8 It is interesting to note in this case that it is the father who was responsible for negotiating with the municipality. This was unusual. 
Given the absence of an 'untainted' vantage point or a pure non-reified consciousness, it might be assumed that much of the radical potential (alluded to by Jameson, 2004) within standpoint theories is precluded. However, I would disagree. Instead, I would suggest that the situated knowledges of those interviewed suggest an understanding of the waterscape that is at the cusp of many of the more recent sociohistorical transformations. In this, perhaps, lie deeper possibilities, ones that prise open understandings of the colonization of the lifeworld through deepening an understanding of the shifting socio-natural relations of the waterscape. As Adorno writes: Greyness could not fill us with despair if our minds did not harbour the concept of different colours, scattered traces of which are not absent from the negative whole' (1990: 3778). In short, we need some sense of a world-beyond-reification, if we are to realistically survey the gloom of reification and shatter its claustrophobic walls from within. We need a sense of multi-dimensionality if we are to perceive the true effects of onedimensionality (Marcuse, 2002). This multi-dimensionality might emerge from the situated knowledges developed in a process of everyday struggle. Tentatively, in the final part of the article, I suggest ways in which such situated knowledges might have been transformed into an active coalition, able to challenge the inequalities produced through these shifting socio-natural relations and able to challenge one-dimensional, reified readings of the waterscape. The example is taken from the Amaoti area of Inanda.

\section{Producing epistemological possibilities}

Amaoti is located on the periphery of Inanda. It comprises several different areas, each named after places of significance to a younger generation of 'comrades' during the struggle years. In the Libya and Palestina sections of Amaoti, up until January 2003, residents were dependent on a water kiosk for their main supply of water. Although some of the basic infrastructure was in place, standpipes still required a connection to the main municipal water network. In the meantime, a private entrepreneur had entered into an agreement with the municipality to fill a tanker with water daily, to drive to Libya and Palestina and to fill the two water tanks in the area. These were locked, and a 'bailiff' would sell water on to residents at what amounted to one of the highest Rand/ $\mathrm{kl}$ rates in the entire municipality. Thus, the entrepreneur was able to pay the bailiff a minimal wage and profit out of the long-delayed connection of the area to the municipal network. Concerns about such a system were expressed in a community workshop in Amaoti, held on 16 January 2003. Residents stated how a previous councillor had promised the community a connection to the water network but two years later they were still waiting. The present councillor urged patience, realizing that such a supply was at the whims of eThekwini Water Services' expansion plans. In late-January, the tanker stopped delivering water to the community, owing to a breakdown in the relationship between the municipality and the private entrepreneur. When the community water supply ceased, roughly a thousand people lost their nearest supply of water. Instead, a new market opened up for entrepreneurs to undertake the wearisome task of carrying loads of water up and down the hill. Relationships changed dramatically with the work of provisioning the household, with water becoming an even greater burden.

On the morning of 11 February 2003, when conducting household interviews in the area, we interviewed one of those carrying wheelbarrow loads of water. He was, as might be expected, hoping to earn a few cents in order to negotiate a way through these hard times. In order to ensure the survival of himself and his family through a period of great insecurity, he had turned to one of the few commodities available to him, his labour power, and had sold this to any local households unable or unwilling to collect the water themselves. It is difficult to generalize from this situation; however, judging from the 
previous discussion cited from Bhambayi, it might be assumed that, as a man in a capitalist and patriarchal society, he would have found it more permissible to be seen carrying water for money at this particular moment (albeit for income and not for a wage in this instance). The wheelbarrow had become the material object in the waterscape with which a man might be happy to be associated, embodying as it does aspects of the commoditized economy.

At the very same moment, others in the community were organizing a militant delegation to the offices of the local councillor in order to bring about a political transformation of the situation. The vast majority of these organizers were women. Several had participated in the community workshop organized in the previous month and their eagerness to act for a radical change to the situation had already been expressed. One woman noted:

We have been working and fighting on these issues during the first session for five years and now it looks like another five year will pass and nothing will be done. Something else needs to be done that is more direct and gets things done (community workshop Amaoti, 16 January 2003).

Clearly, her thoughts were going beyond the coping strategies of the man wheelbarrowing loads of water, as well as beyond the diplomatic and delaying negotiations of the local councillors. The tortuous process of negotiating with the municipality and councillors over previous years involved a struggle to get to grips with the complex of relationships that produced Amaoti's anomalous water politics. After the militant delegation of women had arrived at the councillor's compound, a representative from the municipality was called. On his arrival, the compound was locked and, working with some of the former comrades of the struggle years, the protestors were able to secure a guarantee from the municipality that the community tank would be filled for free on a daily basis. The tap to the tank would no longer be locked and, in short, the community would have free access to a limited supply of water. The political organizing of the women had achieved (temporary) positive results. The radical politics struggled for and developed by the women in this instance, I would suggest, is made possible through the relational understanding of the waterscape developed through years of everyday struggle to ensure access to water. For a moment, this everyday struggle became a self-consciously political one.

There is, of course a substantial body of literature that stresses the importance of such acts in challenging inequalities in the global South. In a South African context, Belinda Bozzoli highlights the importance of what she refers to as 'domestic struggles', arguing that these 'may in fact condition and shape the very form taken by capitalism' (1995: 126). She continues:

It is not only that 'domestic struggles' are the key to unravelling the evolving subordination of women. It is also that they provide a crucial dimension to our understanding of a whole variety of other factors, ranging from the composition of the labour force, to the form of the state (ibid.).

Some of the history of such domestic struggles has been well documented in Durban, from a boycott of municipal beerhalls in 1929 (Maylam, 1996: 11) to beerhall riots in Cato Manor in the 1950s, consisting of complex layers of struggle between men, women and the apartheid state (Edwards, 1996). Although noting the continued gender imbalance, Hemson (1996) has written on the important role played by women in the Inanda marshals movement of the early 1990s.

More recently, Saskia Sassen refers, in a global context, to the 'feminization of survival' (2000). Noting how women are largely responsible for the health and education of household members, she argues that households and whole communities are increasingly dependent on women for their survival' (ibid.: 503). Going beyond a discussion of survival strategies and theories which, potentially, see women as victims of globalization, Daines and Seddon (1994) attempt to document women's responses to 
structural adjustment programmes in order to emphasize the many ways in which women 'fight for survival' and how they challenge, struggle against, and seek to defy structural adjustment in the global South. In a shorter piece, Epprecht (1993) argues for the same, when writing the history of social change in Africa. Thus, he calls for a recovery of women's true role in making this history. In emphasizing the militancy of women's protests through history, he quotes South African political scientist Tom Lodge who writes that exclusively female protest in the apartheid era 'was characterized by an appetite for confrontation qualitatively sharper than that usually displayed by those in which men predominated' (quoted in Epprecht, 1993: 20).

However, the understanding developed in this article and suggested by the examples of Amaoti and KwaMashu is somewhat different. Instead, I suggest that, through struggling to ensure access to water, new conditions of possibility are opened up for radical ways of rethinking Durban's water politics. By rooting this in historically and geographically specific activity, this avoids the essentializing of 'militant third-world woman' often evident in some of the work outlined above (for criticisms, see Mohanty, 1988). Instead, I have attempted to emphasize the manner in which a feminist standpoint is not pre-given but must be struggled for, through exploring contextually rooted and relationally defined 'situated knowledges'. Thus, the protest in Amaoti does not show that the work conducted by women and men in the area places them in a structural position that will automatically either compel them to political activism or compel them to quietism. Nor does it provide sufficient evidence to show that ways of thinking through the waterscape for women are necessarily more militant or radical than for men. Instead, I have argued that an everyday struggle has been transformed, momentarily, into a political struggle and a politically active coalition. Such a political coalition was not simply formed through the abandoning of some false consciousness or through the miraculous appearance of a 'better vantage point'; it was achieved through democratic debate and political action. By arguing for the political possibilities, rooted in situated knowledges that grounded such a protest, I think a hopeful case can be made that this might foreground a radical politics elsewhere.

Overall, I have argued that the waterscape is produced relationally and historically. Through working with others and with the material 'things' of the waterscape - the taps, the water meters, the water bills - power relations are produced and reproduced. In Swyngedouw's (2006) terms, these 'things' are enrolled as actants in new networks. As different individuals relate to the taps and water meters, in different ways, depending on the organization of activity in late capitalist-patriarchy, different conditions of possibility are opened up for thinking through a radical politics of the waterscape.

To what extent might this be a radical feminist as well as a radical environmental politics? In many ways, the examples given are not of a self-consciously feminist politics. As Young (1997) reminds us, perhaps the vast majority of women's groups are not necessarily feminist groups. Perhaps also the majority of protests dominated by women are not necessarily feminist protests. However, in spite of this, crucial work is carried out for developing a feminist politics that might be able to transform the relations that reproduce patriarchy. This work lies predominantly in the linking of the situated knowledges produced within different areas, and in the subsequent topographical charting of the relations of power (Katz, 2004). Gendered assumptions and patriarchal power relations are brought to the fore through such an activity. Although the protest in Amaoti does not show a direct challenge to such relations, it opens the possibility for this to be the case. The target was a more direct one, although in its wake, the protest also made clear the quite different relations men and women have to the waterscape. Secondly, the example opens up the possibility for strategic alliances to be formed between women. Again, this need not be based on an already-constituted group identity, but rather on a recognition of the way in which different people in different areas experience common concerns based on the changing ways in which they produce the waterscape. 


\section{Conclusions}

Feminist standpoint theories and writings on produced natures share many common assumptions. Both build on the methodological commitments of marxism as opposed to a dogmatic, singular reading of the texts of Marx (Lukács, 1971: 1). Both develop relational ontologies and epistemologies. In this article, I seek to bring the commitments and approaches of feminist standpoint theory together with work on the production of nature. In doing this, I have sought to emphasize the gendered division of labour involved in producing urban environments and have argued for a relational view of the created ecosystems we cohabit with human and non-human others. From this relational view, I have suggested opportunities are available to develop specific ways of thinking through political challenges to socio-ecological inequalities.

The empirical study I have developed is based on the everyday work that goes into provisioning households with water in Durban. Women conduct the vast majority of this work. As economic conditions and socially constructed fears of scarcity have met in a fierce coalition, accessing water has become particularly difficult. In some areas, particularly those newly connected to the water network, these difficulties have been temporarily assuaged. However, in other areas immense difficulties have been encountered in accessing sufficient water for a healthy and fulfilling life. These difficulties are related to processes of reification and commodification that can be understood through looking at how the waterscape is produced in the contemporary moment. If we are to look anywhere for a politics of hope within this situation, I suggest that it might begin with the situated knowledges of those engaged in this process of production. Thus, through the relations forged in the unpaid labour of those working the waterscape, the possibility might be opened up for new ways of thinking about the politics of the city.

Alex Loftus (alex.loftus@rhul.ac.uk), Department of Geography, Royal Holloway, University of London, Egham, Surrey, TW20 OEX, UK.

\section{References}

Adorno, T.W. (1990) Negative dialectics. Routledge, London.

Agarwal, B. (1992) The gender and environment debate: lessons from India. Feminist Studies 18, 119-58.

Bailey, R. (2005) Designing a welfare maximising water tariff for Durban with Ramsey pricing principles. Unpublished MBA Thesis, University of KwaZulu Natal, Pietermaritzburg.

Bakker, I. and S. Gill (2003) Power, production and social reproduction: human in/security in the global political economy. Palgrave Macmillan, Basingstoke.

Blaikie, P. (1985) The political economy of soil erosion in developing countries. Longman, New York.

Bozzoli, B. (1995) Marxism, feminism and South African studies. In W. Beinart and S. Dubow (eds.), Segregation and apartheid in twentieth century South Africa, Routledge, London.

Bullard, R. (ed.) (1993) Confronting environmental racism: voices from the grassroots. South End Press, Boston.

Castree, N. (2002) False antitheses? Marxism, nature and actor-networks. Antipode 34, 111-46.

Daines, V. and D. Seddon (1994) Fighting for survival: women's responses to austerity programs. In J. Walton and D. Seddon (eds.), Free markets and food riots, Blackwell, Oxford.

Desfor, G. and R. Keil (2004) Nature and the city: making environmental policy in Toronto and Los Angeles. University of Arizona Press, Tucson.

Eagleton, T. (1994) Ideology. Longman, London.

Edwards, I. (1996) Cato Manor, June 1959. Men, women, crowds, violence, politics and history. In P. Maylam and I. Edwards (eds.), The people's city: African life in twentieth century Durban, University of Natal Press, Pietermaritzburg.

Epprecht, M. (1993) Marxism versus the patriarchy: gender and historical 
materialism in southern Africa. In ISAS Working Paper Series, ISAS, Lesotho.

Gandy, M. (2002) Concrete and clay: reworking nature in New York City. The MIT Press, Cambridge, MA.

Gandy, M. (2005a) Cyborg urbanization: complexity and monstrosity in the contemporary city. International Journal of Urban and Regional Research 29.1, 26-49.

Gandy, M. (2005b) Learning from Lagos. New Left Review 33, 36-52.

Gandy, M. (forthcoming) Landscapes of disaster: water, modernity and urban fragmentation in Mumbai. Environment and Planning A (in press).

Haraway, D. (1991) Symians, cyborgs and women. The reinvention of nature. Free Association Books, London.

Haraway, D. (1993) The promises of monsters: a regenerative politics for inappropriate/d others. In L. Grossberg, C. Nelson and P.A. Treichler (eds.), Cultural studies, Routledge, New York.

Haraway, D. (1996) Modest_Witness @SSecond_Millenium.FemaleMan@_Meets_ Oncomouse $^{\mathrm{TM}}$. Routledge, New York.

Haraway, D. (2004) There are always more things going on than you thought! Methodologies as thinking technologies. In The Haraway Reader, Routledge, London.

Harding, S. (1986) The science question in feminism. Cornell University Press, Ithaca.

Harding, S. (2004) Introduction. In S. Harding (ed.), The feminist standpoint theory reader, Routledge, London.

Hartmann, H. (1981) The unhappy marriage of Marxism and feminism: towards a more progressive union. In L. Sargent (ed.), Women and revolution, Black Rose Books, Montreal.

Hartsock, N. (1983a) The feminist standpoint: developing the ground for a specifically feminist historical materialism. In S. Harding and M. Hintikka (eds.), Discovering reality: feminist perspectives on epistemology, metaphysics, methodology and philosophy of science, Kluwer Academic, Dordrecht.

Hartsock, N. (1983b) Money, sex and power: towards a feminist historical materialism. Longman, London.

Hartsock, N. (1998) The feminist standpoint revisited and other essays. Westview, Oxford.

Harvey, D. (1982) The limits to capital. University of Chicago Press, Chicago.
Harvey, D. (1996) Justice, nature and the geography of difference. Basil Blackwell, Oxford.

Hemson, D. (1996) 'For sure you are going to die!' Political participation and the comrade movement in Inanda, KwaZulu Natal.

Social Dynamics 22.2, 74-105.

Heynen, N. (2006) Justice of eating in the city: the political ecology of urban hunger. In N. Heynen, M. Kaika and E. Syngedouw (eds.), In the nature of cities: urban political ecology and the politics of urban metabolism, Routledge, London.

Heynen, N., M. Kaika and E. Syngedouw (eds.) (2006) In the nature of cities: urban political ecology and the politics of urban metabolism. Routledge, London.

Holloway, J. (2002) Change the world without taking power. Pluto Press, London.

Jameson, F. (2004) History and class consciousness as an 'unfinished project'. In S. Harding (ed.), The feminist standpoint theory reader, Routledge, London.

Kaika, M. (2005) City of flows: modernity, nature and the city. Routledge, London.

Kasrils, R. (2000) Delivery of free water to the poor: media statement by Minister of Water Affairs and Forestry, Mr Ronnie Kasrils, MP WWW document. URL: http:// www.dwaf.gov.za/Communications/ PressReleases/2000/Free\%20Water.doc (accessed 12 January 2004).

Katz, C. (2004) Growing up global: economic restructuring and children's everyday lives. University of Minnesota Press, Minneapolis.

Kinmont, A. (1959) Report on the water supply of Durban. Durban City Council.

Loftus, A. (2004) Free water as commodity: the paradoxes of Durban's water service transformations. In D. Macdonald and G. Ruiters (eds.), The age of commodity: water privatization in southern Africa, Earthscan, London.

Loftus, A. (2005) A political ecology of water struggles in Durban, South Africa. Unpublished DPhil thesis, Oxford University.

Loftus, A. (2006a) The metabolic processes of capital accumulation in Durban's waterscape. In N. Heynen, M. Kaika and E. Swyngedouw (eds.), In the nature of cities: urban political ecology and the politics of urban metabolism, Routledge, London.

Loftus, A. (2006b) Reification and the dictatorship of the water meter. Antipode $38.5,1023-44$.

Lukács, G. (1971) History and class consciousness: studies in Marxist dialectics. Merlin Press, London. 
Macleod, N. (1997) The Durban water tank system. Paper presented at the $23^{\text {rd }}$ WEDC (Water Engineering and Development Centre) Conference, Durban.

Marcuse, H. (2002 [1964]) One-dimensional man: studies in the ideology of advanced industrial society. Routledge, London.

Maylam, P, (1996) The struggle for space in twentieth century Durban. In P. Maylam and I. Edwards (eds.), The people's city: African life in twentieth century Durban, University of Natal Press, Pietermaritzburg.

Marx, K. (1974) Early writings. Penguin, London.

Marx, K. (1976) Capital. Penguin Classics, London.

Marx, K. and F. Engels (1970) The German ideology. Lawrence and Wishart, London.

Meillassoux, C. (1981) Maidens, meal and money: capitalism and the domestic community. Cambridge University Press, Cambridge.

Merchant, C. (1992) Radical ecology: the search for a livable world. Routledge, London.

Mohanty, C.T. (1988) Under Western eyes: feminist scholarship and colonial discourses. Feminist Review 30, 61-88.

Naess, A. (1989) Ecology, community and lifestyle. Cambridge University Press, Cambridge.

Nesmith, C. and S. Radcliffe (1993) (Re)Mapping mother earth: a geographical perspective on environmental feminisms. Environment and Planning D: Society and Space 11, 379-94.

New, C. (1997) Man bad, woman good? Essentialisms and ecofeminisms. New Left Review 216, 79-93.

Nightingale, A. (2006) The nature of gender: work, gender and environment.

Environment and Planning D: Society and Space 24, 165-85

Ollman, B. (1973) Alienation: Marx's conception of man in capitalist society. Cambridge University Press, Cambridge.

Page, B. (2005) Paying for water and the geography of commodities. Transactions of the Institute of British Geographers 30.3, 293-306.

Palmer Development Group (2000) PPP and the poor in water and sanitation. Case study: Durban, South Africa. WEDC, Loughborough.

Peet, R. and M.J. Watts (2004) Liberation ecologies: environment, development, social movements. Second edition, Routledge, New York.

Plumwood, V. (1993) Feminism and the mastery of nature. Routledge, London.

Robbins, P. (2004) Political ecology. Blackwell, Oxford.

Sachs, C. (1994) Rural women's environmental activism in the USA. In S. Whatmore, T. Marsden and P. Lowe (eds.), Gender and rurality, John Wiley \& Sons, London.

Sassen, S. (2000) Women's burden: countergeographies of globalization and the feminization of survival. International Affairs 53.2, 504-24.

Smith, N. (1984) Uneven development: nature, capital and the production of space. Basil Blackwell, Oxford.

Swyngedouw, E. (1997) Power, nature, and the city. The conquest of water and the political ecology of urbanization in Guayaquil, Ecuador: 1880-1990. Environment and Planning A 29, 311-32.

Swyngedouw, E. (1999) Modernity and hybridity: nature, regeneracionismo, and the production of the Spanish waterscape, 1890-1930. Annals of the Association of American Geographers 89.3, 443-65.

Swyngedouw, E. (2004) Social power and the urbanization of water. Oxford University Press, Oxford.

Swyngedouw, E. (2006) Circulations and metabolisms: (hybrid) natures and (cyborg) cities. Science as Culture 15.2, 105-22.

Swyngedouw, E. (forthcoming) Techno-natural revolutions ? the scalar politics of Franco's hydro-social dream for Spain. Transactions of the IBG.

Swyngedouw, E. and N. Heynen (2003) Urban political ecology and the politics of scale. Antipode, 35.5, 898-918.

Swyngedouw, E., M. Kaika and E. Castro (2002) Urban water: a political-ecology perspective. Built Environment 28.2, 124 37.

Weber, M. (1968) Economy and society: an outline of interpretive sociology. Bedminster Press, New York.

Whatmore, S. (2002) Hybrid geographies: natures cultures spaces. Sage, London.

Wolpe, H. (1972) Capitalism and cheap labour power: from segregation to apartheid. Economy and Society 1.4, 42556.

Young, I.M. (1981) Beyond the unhappy marriage: a critique of dual systems theory. In L. Sargent (ed.), Women and revolution, South End Press, Boston. 
Young, I.M. (1997) Gender as seriality. In I.M. Young, Intersecting voices: dilemmas of gender, political philosophy and policy, Princeton University Press, Princeton, NJ.
Zimmerer, K and T. Bassett (2003) Political ecology. Guilford Press, New York.

\section{Résumé}

Cet article tente d'associer un travail récent sur 'la production de nature' avec des théories du point de vue féministe. Il s'agit d'explorer des potentiels de changement démocratique dans la ville sud-africaine de Durban. Malgré leurs postulats méthodologiques communs, on a rarement essayé de faire dialoguer les deux corpus. L'article présente d'abord quelques-uns des fondements théoriques à la base des deux théories. Il explique ensuite de quelles manières une approche relationnelle des environnements urbains éclaire la politique de fourniture d'eau à Durban. De là, il suggère qu'une approche du point de vue féministe pourrait déboucher sur des possibilités différentes de changement démocratique. Toutefois, il faudrait commencer, non par une vision romantique d'une conscience pure ou non-réifiée du socio-naturel, mais par les connaissances situées, nées de la lutte pour survivre dans un monde défini par des rapports sociaux à la fois capitalistes et non-capitalistes. 